\title{
Advances of the interleukin-21 signaling pathway in immunity and angiogenesis (Review)
}

\author{
MING-JIE YUAN ${ }^{1}$ and TAO WANG ${ }^{2}$ \\ ${ }^{1}$ Department of Cardiology, Renmin Hospital of Wuhan University, Wuhan, Hubei 430060, P.R. China; \\ ${ }^{2}$ Cardiovascular Research Center, University of Virginia, Charlottesville, VA 22908, USA
}

Received January 27, 2016; Accepted April 25, 2016

DOI: $10.3892 /$ br.2016.665

\begin{abstract}
Interleukin-21 (IL-21) and its receptor (IL-21R) are broadly expressed on human B cells, activated $\mathrm{T}$ cells and other myeloid cells. IL-21 cooperates with IL-6 and transforming growth factor- $\beta$ to regulate T-cell differentiation. IL-21-mediated human B cell and dendritic cells differentiation requires signal transducer and activator of transcription 3 (STAT3), and also induces B-cell apoptosis dependents on the Toll-like receptor signal. Recently, in vitro and in vivo experiments showed that IL-21/IL-21R regulate angiogenesis through STAT3. IL-21 signaling pathways are complex due to its cooperation with other transcriptional factors, such as interferon regulatory factor 4 and granulocyte-macrophage colony-stimulating factor. The Janus kinase-STAT pathway has been the most extensively studied. With the increase in the understanding of IL-21 biology in the context of each specific disease or pathological condition, IL-21 could be a new therapeutic target for immune-related disease.
\end{abstract}

\section{Contents}

1. Introduction

2. Function of IL-21 on immune cells

3. Signaling by IL-21

4. IL-21 and angiogenesis

5. Potential therapeutic effect of IL-21

6. Conclusion

\section{Introduction}

Interleukin-21 (IL-21) and its receptor (IL-21R) were identified in 2000 (1). IL-21 is primarily produced by cluster of

Correspondence to: Professor Ming-Jie Yuan, Department of Cardiology, Renmin Hospital of Wuhan University, 238 Jiefang Road, Wuhan, Hubei 430060, P.R. China

E-mail: yuanmj8341@163.com

Key words: interleukin-21/interleukin-21 receptor, immunity, signaling pathway, angiogenesis, signal transducer and activator of transcription 3 differentiation $4^{+}\left(\mathrm{CD}^{+}\right)$cells and natural killer cells, while IL-21R is broadly expressed on human B cells, activated $\mathrm{T}$ cells and other myeloid cells $(2,3)$. IL-21 is a pleiotrophic cytokine that is composed of four $\alpha$-helical bundles. IL-21R shares the common cytokines receptor $\gamma$ chain $(\gamma \mathrm{c})$ with the IL-2 family cytokines, such as IL-4, IL-7, IL-9 and IL-15 (4). In addition, IL-21R has a distinct $\alpha$ chain, and contains six tyrosine residues in the cytoplasmic domain $(3,5)$. This specific IL-21R structure differentiates IL-21R from IL-2R. IL-21 exerts its effect on a broad range of cell types. Increasing evidence shows that IL-21 potently regulates innate and adaptive immune response (6-8). Furthermore, the role of IL-21 in angiogenesis has also been studied $(9,10)$. In the present review, the recent advances regarding the role of IL-21 in immune cells and angiogenesis are discussed.

\section{Function of IL-21 on immune cells}

Although IL-21 is not required for $\mathrm{CD}^{+}{ }^{+} \mathrm{T}$-cell development, it contributes to the functional differentiation of several subsets $(11,12)$, such as T helper 2 (Th2) cells $(13,14)$, Th17 (15,16) and follicular helper T (Tfh) cells $(17,18)$. Th17 and Tfh cells can be generated in the absence of IL-21/IL-21R (16), indicating an IL-21-independent pathway for their development. IL-21 is produced by the Th17 cells, and transforming growth factor- $\beta$ (TGF- $\beta$ ) and IL-6 can activate Th17 cells even in the absence of IL-21 $(19,20)$. IL-21 regulates the transcription factors B-cell lymphoma 6 (BCL-6) and MAF, which are important to the transcriptional programme of the Tfh cells $(21,22)$. IL-6 can induce Tfh-cell differentiation via its induction of IL-21 production. The number of Treg cells is increased in IL-21- and IL-6-knockout mice, and TGF- $\beta$ signaling enhances the generation of Treg cells in the absence of either IL-21 or IL-6 $(23,24)$. Thus, IL-21 appears to have a complementary role in regulating $\mathrm{CD}^{+} \mathrm{T}$-cell differentiation.

B-cell expression of IL-21R notably exceeds that of T cells. A large number of studies confirm that IL-21 involved in the regulation of both $\mathrm{B}$ cell proliferation and maturation. IL-21 can stimulate B cells proliferation and differentiation in the context of a co-stimulatory T-cell signal. IL-21-mediated human B-cell differentiation requires signal transducer and activator of transcription 3 (STAT3), and cannot be compensated by alternative signaling pathways (25). The effect of IL-21 can be augmented by IL-2 or IL-10, and 
IL-21 induces IL-10 in human B cells and interacts with TGF- $\beta(26,27)$. In particular, IL-21 promotes B cells differentiation to Ig-producing plasma through its induction of B lymphocyte-induced maturation protein-1 (28), which is a transcription factor critical for plasma cell formation. Notably, IL-21 also induces B cell apoptosis either in the absence of a T-cell signal or in the activation of a Toll-like receptor signal (29). The pro-apoptotic activity of IL-21 results from the induction of BCL-2, which is a pro-apoptotic protein.

IL-21 has broad actions on T and B cells, but its innate immunity is poorly understood. IL-21 has a potent inhibitory effect on granulocyte-macrophage colony-stimulating factor (GM-CSF)-induced dendritic cells (DCs) (30). IL-21 induces apoptosis of conventional DCs (cDCs) via STAT3 and inhibiting Bim, and this effect is prevented by GM-CSF, which partially opposes the biological action by these cytokines. Furthermore, the number of STAT3 sites was reduced in the presence of GM-CSF when DCs were treated with IL-21, and GM-CSF primarily activates STAT5 instead of STAT3 and inhibits Bim (31). These findings suggest that IL-21-induced STAT3-dependent apoptosis of DCs provides a mechanism for alleviating the immune response, and IL-21 has a cross-negative regulation with GM-CSF.

\section{Signaling by IL-21}

IL-21 regulates the innate and adaptive immune responses via heterodimers of the IL-21R and the common cytokine receptor $\gamma$ c1. IL-21 signals via the Janus kinase (JAK)-STAT signaling pathway $(25,26)$, the mitogen-activated protein kinase signaling pathway and the phosphoinositide 3-kinase-AKT signaling pathway (2). Of these, the JAK-STAT pathway has been the most extensively studied. In T cells, IL-21 activates STAT3 more than STAT1 and STAT5.STAT1 and STAT3 have partially opposing roles in IL-21 signaling. RNA-sequence analysis showed that STAT1 and STAT3 are critical for IL-21-mediated gene regulation, including Tbx21 and interferon $\gamma$ (32). Notably, IL-21-induced expression of suppressor of cytokine signaling 3 (Socs3) and Socs1 are decreased in Stat $3^{-/-}$cells (33). SOCS3 and SOCS1 can negatively regulate STAT protein phosphorylation, and this may in part explain the opposing roles of STAT1 and STAT3 in IL-21 function in $\mathrm{CD}^{+} \mathrm{T}$ cells. In cDCs, IL-21 induces IL-1 $\beta$ production via a STAT3 dependent and nuclear factor- $\kappa \mathrm{B}$ independent pathway. Furthermore, this processing in $\mathrm{cDCs}$ does not require caspase- 1 or caspase-8, but depends on IL-21-mediated death (34). IL-21 can induce the expression of PR domain containing 1, with ZNF domain in multiple B lymphoma cell lines, and IL-21 induces STAT3 binding also bound interferon regulatory factor 4 (IRF4) in vivo $(35,36)$, and Irf4 ${ }^{-/}$mice showed impaired IL-21 induced Tfh cells differentiation (37). These results reveal broad cooperative gene regulation by STAT3 and IRF4. In T cells, numerous target genes of IL-21 are regulated through basic leucine zipper transcription factor, ATF-like, JUN, IRF4 and STAT3 (37,38). Notably, these transcription factors are also potential targets through which IL-21 signaling may be regulated. Our recent study reported that IL-21 activated STAT3 in HUVECs exposed to ischemia conditions; however, there were no significant changes in
STAT1, AKT1 or extracellular-signal-regulated kinase 1/2 (ERK1/2) phosphorylation at any time point following IL-21 treatment (9).

\section{IL-21 and angiogenesis}

It has been shown that IL-21R exists in endothelial cells (ECs), which is a key process in the formation of new blood vessels during angiogenesis. IL-21 treatment decreases EC proliferation and sprouting in vitro. Furthermore, in a tumor mouse model, IL-21 inhibited tumor angiogenesis in vivo and decreased angiogenesis vascular endothelial growth factor A and its receptors (10). Another study demonstrated conflicting results, in which genetic ablation of IL-21 in $\mathrm{Apc}^{\mathrm{min} /+}$ mice reduced STAT3 activation and diminished cytokines, including IL- 6 and tumor necrosis factor- $\alpha$, and decreased angiogenesis in the lesions (8).

In our recent study of a mouse model with surgical hindlimb ischemia (HLI), the IL-21R levels were higher in the EC-enriched fraction isolated from ischemic hindlimb muscle. Furthermore, HUVECs showed 10-fold IL-21R expression following hypoxia and serum starvation in vitro. IL-21 treatment increased cell viability, decreased cell apoptosis and augmented tube formation in HUVECs under ischemic conditions. Knockout IL-21R resulted in less perfusion recovery following HLI in vivo. In particular, the activated STAT3 pathway and increase in the BCL-2/BCL-2-associated $\mathrm{X}$ protein ratio were involved in the in vitro and in vivo experiments (9). These results suggest that the elevated IL-21R levels in EC in ischemia muscle are adaptive.

\section{Potential therapeutic effect of IL-21}

Numerous studies have shown that IL-21 has therapeutic effects in animal models of a wide range of diseases [including cancer (12), immunity-deficient disease (39), type 1 diabetes (40) and inflammatory bowel disease (41)] and various clinical trials are underway (42).

An investigation regarding the association between IL-21 levels and myocardial function following acute myocardial showed that plasma IL-21 concentration correlated significantly with left ventricular end-systolic volume index, and multivariate analysis suggested that IL-21 was an independent predictor of remodeling. Furthermore, IL-21 was also significantly associated with higher tissue inhibitor of metalloproteinases-4 (TIMP-4) concentrations and lower MMP-9 concentrations (43). A previous experiment demonstrated that IL-21R was expressed on cardiac fibroblasts (44), and whether IL-21 may directly stimulate MMP/TIMP release within the myocardium is unknown and merits further study.

\section{Conclusion}

IL-21 has been implicated in broad immunological processes since its discovery in 2000. IL-21 regulates at least 3 pathways (STAT3, ERK1/2 and AKT-1), which can either enhance cell survival or pro-apoptosis in different cell lines. IL-21 signaling pathways are complex due to their cooperation with other transcriptional factors. With the improvement of our 
understanding in IL-21 biology regarding each specific disease or pathological condition, IL-21 could be a new therapeutic target for immune relative disease.

\section{Acknowledgements}

The present study was partially supported by National Natural Science Foundation of China (grant no. 81300315).

\section{References}

1. Parrish-Novak J, Dillon SR, Nelson A, Hammond A, Sprecher C, Gross JA, Johnston J, Madden K, Xu W, West J, et al: Interleukin 21 and its receptor are involved in NK cell expansion and regulation of lymphocyte function. Nature 408: 57-63, 2000.

2. Spolski R and Leonard WJ: Interleukin-21: A double-edged sword with therapeutic potential. Nat Rev Drug Discov 13 379-395, 2014

3. Mehta DS, Wurster AL and Grusby MJ: Biology of IL-21 and the IL-21 receptor. Immunol Rev 202: 84-95, 2004.

4. Ozaki K, Kikly K, Michalovich D, Young PR and Leonard WJ: Cloning of a type I cytokine receptor most related to the IL-2 receptor beta chain. Proc Natl Acad Sci USA 97: $11439-11444,2000$.

5. Asao H, Okuyama C, Kumaki S, Ishii N, Tsuchiya S, Foster D and Sugamura K: Cutting edge: The common gamma-chain is an indispensable subunit of the IL-21 receptor complex. J Immunol 167: 1-5, 2001.

6. Spolski R and Leonard WJ: Interleukin-21: Basic biology and implications for cancer and autoimmunity. Annu Rev Immunol 26: 57-79, 2008.

7. Vogelzang A, McGuire HM, Liu SM, Gloss B, Mercado K, Earls P, Dinger ME, Batten M, Sprent J and King C: IL-21 contributes to fatal inflammatory disease in the absence of $\mathrm{Foxp}^{+}{ }^{+} \mathrm{T}$ regulatory cells. J Immunol 192: 1404-1414, 2014.

8. De Simone V, Ronchetti G, Franzè E, Colantoni A, Ortenzi A, Fantini MC, Rizzo A, Sica GS, Sileri P, Rossi P, et al: Interleukin-21 sustains inflammatory signals that contribute to sporadic colon tumorigenesis. Oncotarget 6: 9908-9923, 2015.

9. Kanada M, Bachmann MH, Hardy JW, Frimannson DO, Bronsart L, Wang A, Sylvester MD, Schmidt TL, Kaspar RL, Butte MJ, et al: Differential fates of biomolecules delivered to target cells via extracellular vesicles. Proc Natl Acad Sci USA 112: E1433-E1442, 2015.

10. Castermans K, Tabruyn SP, Zeng R, van Beijnum JR, Eppolito C, Leonard WJ, Shrikant PA and Griffioen AW: Angiostatic activity of the antitumor cytokine interleukin-21. Blood 112: 4940-4947, 2008.

11. Leonard WJ and Spolski R: Interleukin-21: A modulator of lymphoid proliferation, apoptosis and differentiation. Nat Rev Immunol 5: 688-698, 2005.

12. Davis MR, Zhu Z, Hansen DM, Bai Q and Fang Y: The role of IL-21 in immunity and cancer. Cancer Lett 358: 107-114, 2015.

13. Pesce J, Kaviratne M, Ramalingam TR, Thompson RW, Urban JF Jr, Cheever AW, Young DA, Collins M, Grusby MJ and Wynn TA: The IL-21 receptor augments Th2 effector function and alternative macrophage activation. J Clin Invest 116: 2044-2055, 2006

14. Fröhlich A, Marsland BJ, Sonderegger I, Kurrer M, Hodge MR, Harris NL and Kopf M: IL-21 receptor signaling is integral to the development of Th2 effector responses in vivo. Blood 109: 2023-2031, 2007.

15. Zhou L, Ivanov II, Spolski R, Min R, Shenderov K, Egawa T, Levy DE, Leonard WJ and Littman DR: IL-6 programs T(H)-17 cell differentiation by promoting sequential engagement of the IL-21 and IL-23 pathways. Nat Immunol 8: 967-974, 2007.

16. Nurieva R, Yang XO, Martinez G, Zhang Y, Panopoulos AD, Ma L, Schluns K, Tian Q, Watowich SS, Jetten AM, et al: Essential autocrine regulation by IL-21 in the generation of inflammatory T cells. Nature 448: 480-483, 2007.

17. Nurieva RI, Chung Y, Hwang D, Yang XO, Kang HS, Ma L, Wang YH, Watowich SS, Jetten AM, Tian Q, et al: Generation of T follicular helper cells is mediated by interleukin-21 but independent of $\mathrm{T}$ helper 1,2 , or 17 cell lineages. Immunity 29 : $138-149,2008$
18. Eto D, Lao C, DiToro D, Barnett B, Escobar TC, Kageyama R, Yusuf I and Crotty S: IL-21 and IL-6 are critical for different aspects of B cell immunity and redundantly induce optimal follicular helper CD4 T cell (Tfh) differentiation. PLoS One 6: e17739, 2011.

19. Karnowski A, Chevrier S, Belz GT, Mount A, Emslie D, D'Costa K, Tarlinton DM, Kallies A and Corcoran LM: $\mathrm{B}$ and $\mathrm{T}$ cells collaborate in antiviral responses via IL-6, IL-21, and transcriptional activator and coactivator, Oct2 and OBF-1. J Exp Med 209: 2049-2064, 2012.

20. Kastirr I, Maglie S, Paroni M, Alfen JS, Nizzoli G, Sugliano E, Crosti MC, Moro M, Steckel B, Steinfelder S, et al: IL-21 is a central memory $\mathrm{T}$ cell-associated cytokine that inhibits the generation of pathogenic Th1/17 effector cells. J Immunol 193: 3322-3331, 2014.

21. Bauquet AT, Jin H, Paterson AM, Mitsdoerffer M, Ho IC, Sharpe AH and Kuchroo VK: The costimulatory molecule ICOS regulates the expression of c-Maf and IL-21 in the development of follicular T helper cells and TH-17 cells. Nat Immunol 10: $167-175,2009$.

22. Nurieva RI, Chung Y, Martinez GJ, Yang XO, Tanaka S, Matskevitch TD, Wang YH and Dong C: Bcl6 mediates the development of T follicular helper cells. Science 325: 1001-1005, 2009.

23. Korn T, Bettelli E, Gao W, Awasthi A, Jäger A, Strom TB, Oukka $M$ and Kuchroo VK: IL-21 initiates an alternative pathway to induce proinflammatory $\mathrm{T}(\mathrm{H}) 17$ cells. Nature 448 : 484-487, 2007.

24. Attridge K, Wang CJ, Wardzinski L, Kenefeck R, Chamberlain JL, Manzotti C, Kopf M and Walker LS: IL-21 inhibits T cell IL-2 production and impairs Treg homeostasis. Blood 119: 4656-4664, 2012.

25. Berglund LJ, Avery DT, Ma CS, Moens L, Deenick EK, Bustamante J, Boisson-Dupuis S, Wong M, Adelstein S, Arkwright PD, et al: IL-21 signalling via STAT3 primes human naive $B$ cells to respond to IL-2 to enhance their differentiation into plasmablasts. Blood 122: 3940-3950, 2013.

26. Deenick EK, Avery DT, Chan A, Berglund LJ, Ives ML, Moens L, Stoddard JL, Bustamante J, Boisson-Dupuis S, Tsumura M, et al: Naive and memory human B cells have distinct requirements for STAT3 activation to differentiate into antibody-secreting plasma cells. J Exp Med 210: 2739-2753, 2013.

27. Avery DT, Bryant VL, Ma CS, de Waal Malefyt R and Tangye SG: IL-21-induced isotype switching to $\operatorname{IgG}$ and $\operatorname{IgA}$ by human naive B cells is differentially regulated by IL-4. J Immunol 181: 1767-1779, 2008.

28. Ozaki K, Spolski R, Ettinger R, Kim HP, Wang G, Qi CF, Hwu P, Shaffer DJ, Akilesh S, Roopenian DC, et al: Regulation of $B$ cell differentiation and plasma cell generation by IL-21, a novel inducer of Blimp-1 and Bcl-6. J Immunol 173: 5361-5371, 2004.

29. Liu BS, Stoop JN, Huizinga TW and Toes RE: IL-21 enhances the activity of the TLR-MyD88-STAT3 pathway but not the classical TLR-MyD88-NF- $\mathrm{BB}$ pathway in human B cells to boost antibody production. J Immunol 191: 4086-4094, 2013.

30. Brandt K, Bulfone-Paus S, Foster DC and Rückert R: Interleukin-21 inhibits dendritic cell activation and maturation. Blood 102: 4090-4098, 2003

31. Wan CK, Oh J, Li P, West EE, Wong EA, Andraski AB, Spolski R, Yu ZX, He J, Kelsall BL, et al: The cytokines IL-21 and GM-CSF have opposing regulatory roles in the apoptosis of conventional dendritic cells. Immunity 38: 514-527, 2013.

32. Wan CK, Andraski AB, Spolski R, Li P, Kazemian M, Oh J, Samsel L, Swanson PA II, McGavern DB, Sampaio EP, et al: Opposing roles of STAT1 and STAT3 in IL-21 function in CD4 ${ }^{+}$ T cells. Proc Natl Acad Sci USA 112: 9394-9399, 2015.

33. Strengell M, Lehtonen A, Matikainen S and Julkunen I: IL-21 enhances SOCS gene expression and inhibits LPS-induced cytokine production in human monocyte-derived dendritic cells. J Leukoc Biol 79: 1279-1285, 2006.

34. Wan CK, Li P, Spolski R, Oh J, Andraski AB, Du N, Yu ZX, Dillon CP, Green DR and Leonard WJ: IL-21-mediated non-canonical pathway for IL-1 $\beta$ production in conventional dendritic cells. Nat Commun 6: 7988, 2015

35. Huber M, Brüstle A, Reinhard K, Guralnik A, Walter G, Mahiny A, von Löw E and Lohoff M: IRF4 is essential for IL-21-mediated induction, amplification, and stabilization of the Th17 phenotype. Proc Natl Acad Sci USA 105: 20846-20851, 2008. 
36. Kwon H, Thierry-Mieg D, Thierry-Mieg J, Kim HP, Oh J, Tunyaplin C, Carotta S, Donovan CE, Goldman ML, Tailor P, et al: Analysis of interleukin-21-induced Prdm1 gene regulation reveals functional cooperation of STAT3 and IRF4 transcription factors. Immunity 31: 941-952, 2009.

37. Li P, Spolski R, Liao W, Wang L, Murphy TL, Murphy KM and Leonard WJ: BATF-JUN is critical for IRF4-mediated transcription in T cells. Nature 490: 543-546, 2012.

38. Glasmacher E, Agrawal S, Chang AB, Murphy TL, Zeng W, Vander Lugt B, Khan AA, Ciofani M, Spooner CJ, Rutz S, et al: A genomic regulatory element that directs assembly and function of immune-specific AP-1-IRF complexes. Science 338: 975-980, 2012.

39. Kotlarz D, Ziętara N, Uzel G, Weidemann T, Braun CJ, Diestelhorst J, Krawitz PM, Robinson PN, Hecht J, Puchałka J, et al: Loss-of-function mutations in the IL-21 receptor gene cause a primary immunodeficiency syndrome. J Exp Med 210: 433-443, 2013.

40. Spolski R, Kashyap M, Robinson C, Yu Z and Leonard WJ: IL-21 signaling is critical for the development of type I diabetes in the NOD mouse. Proc Natl Acad Sci USA 105: 14028-14033, 2008.
41. Salzer E, Kansu A, Sic H, Májek P, Ikincioğullari A, Dogu FE, Prengemann NK, Santos-Valente E, Pickl WF, Bilic I, et al: Early-onset inflammatory bowel disease and common variable immunodeficiency-like disease caused by IL-21 deficiency. J Allergy Clin Immunol 133: 1651-1659.e12, 2014.

42. Tangye SG: Advances in IL-21 biology-enhancing our understanding of human disease. Curr Opin Immunol 34: 107-115, 2015.

43. Weir RA, Miller AM, Petrie CJ, Clements S, Steedman T, Dargie HJ, Squire IB, Ng LL, McInnes IB and McMurray JJ: Interleukin-21 - a biomarker of importance in predicting myocardial function following acute infarction? Cytokine 60 : 220-225, 2012

44. Monteleone G, Caruso R, Fina D, Peluso I, Gioia V, Stolfi C, Fantini MC, Caprioli F, Tersigni R, Alessandroni L, et al: Control of matrix metalloproteinase production in human intestinal fibroblasts by interleukin 21. Gut 55: 1774-1780, 2006. 